\title{
The Adaptive Degradation of L-Histidine by Paracolobactrum aerogenoides
}

\author{
BY H. TRISTRAM \\ Department of Botany, University College London, W.C. 1
}

(Received 22 April 1960)

\begin{abstract}
SUMMARY
The characteristics of an induced enzyme system responsible for the degradation of L-histidine by a soil organism were studied. Induction could be achieved by exposing cells to L-histidine, D-histidine, urocanate, $\beta$-alanyl-L-histidine or L-histidylL-histidine, but not by exposure to a variety of other imidazoles. The kinetics of induction by $\mathrm{L}$ - and $\mathrm{D}$-histidine differed considerably and the D-isomer was shown to be metabolized only very slowly by fully induced cells. Chloramphenicol and DL- $p$-fluorophenylalanine strongly inhibited enzyme synthesis, whilst a variety of purine and pyrimidine analogues were without effect. Nitrogen starvation of noninduced cells decreased but did not completely prevent the appearance of the enzyme system on induction with D-histidine. Non-induced cells possess a low level of 'basal' enzymes before exposure to an inducing substance.
\end{abstract}

\section{INTRODUCTION}

The pathway of L-histidine degradation has been studied in both animal tissues and bacteria. These studies led to the recognition of urocanic acid ( $\beta$-imidazole acrylic acid) and glutamic acid as intermediates in histidine breakdown, and have been briefly reviewed by Tabor (1955) and Greenberg (1954). Tabor \& Hayaishi (1952) studied the degradation of histidine by Pseudomonas fluorescens, and Tabor and his co-workers showed that extracts of this organism degraded L-histidine to ammonia, formate and glutamate; urocanate was implicated as an intermediate (Tabor, 1955). Magasanik \& Bowser (1955) described similar experiments with Aerobacter aerogenes. The pathway of histidine breakdown in this organism resembled closely that found in Pseudomonas fluorescens, though differed in detail. Wickremasinghe \& Fry (1954) demonstrated the formation of urocanate and glutamate during the breakdown of histidine by Clostridium tetanomorphum. Suda, Miyahara, Tomihata \& Kato (1952) reported that the enzymes responsible for histidine degradation in a pseudomonad isolated from soil were inducible, and Magasanik (1953) presented similar evidence for Aerobacter aerogenes. Tristram (1953) presented a preliminary report of the induced breakdown of $\mathrm{L}$-histidine by a soil organism. The purpose of this paper is to examine the factors affecting the induction in this organism.

\section{METHODS}

Organism. The organism used in this work was originally isolated from soil and given the number 232. It was subsequently identified by Dr M. E. Rhodes (Reading University) as a strain of Paracolobactrum aerogenoides (Bergey's Manual, 1957). 
Chemicals. L- and D-histidine were obtained from Hoffman La Roche; urocanic acid, DL- $p$-fluorophenylalanine, DL-ethionine and $\beta$-2-L-thienylalanine from L. Light and Co. Colnbrook; purine and pyrimidine analogues from Sigma Chemical Co.; histamine and benzimidazole from British Drug Houses Ltd.; chloromycetin (chloramphenicol) from Parke, Davis and Co.; imidazole and 4:5 imidazole dicarboxylic acid from Eastman Kodak, and inorganic salts of 'Analar' quality from British Drug Houses Ltd. The Radiochemical Centre, Amersham, supplied [2-ring${ }^{14} \mathrm{C}$ ]-L-histidine, and $\beta$-(pyrazolyl-3)-alanine was prepared by Professor $\mathrm{Dr} \mathbf{R}$. Hüttel of Munich.

Media and cultivation. Unless otherwise stated the organism was grown on a medium containing $150 \mathrm{ml} .0 \cdot 2 \mathrm{M}-\mathrm{KH}_{2} \mathrm{PO}_{4}$ with the following additions: glucose, 10.0 g.; $\mathrm{NH}_{4} \mathrm{Cl}, 2.0$ g.; $\mathrm{MgSO}_{4} \cdot 7 \mathrm{H}_{2} \mathrm{O}, 0.1$ g.; $\mathrm{NaCl}, 1.0$ g.; $\mathrm{FeSO}_{4} .7 \mathrm{H}_{2} \mathrm{O}$, trace; $\mathrm{N}-\mathrm{NaOH}$ to $\mathrm{pH} \mathrm{7.2} \mathrm{(about} 21 \mathrm{ml}$.) and Pyrex-distilled water to 11 . Cultures were maintained as slopes on the above medium with the addition of $1.5 \%(w / v)$ Difco agar and after incubation at $30^{\circ}$ stored at $4^{\circ}$. Cells for metabolic experiments were grown in $75 \mathrm{ml}$. portions of liquid medium contained in $250 \mathrm{ml}$. Erlenmeyer flasks, inoculated with $2 \mathrm{ml}$. of an actively growing culture and incubated by shaking for $18 \mathrm{hr}$. at $30^{\circ}$. The organism was harvested by centrifugation and resuspended in $0.067 \mathrm{~m}$ phosphate buffer, $\mathrm{pH} \mathrm{7.2}$. The rate of endogenous respiration of cells immediately after harvesting was high and, unless otherwise stated, suspensions were starved overnight in the same phosphate buffer in shaken flasks at $30^{\circ}$, whereupon the rate of endogenous respiration fell to a low and constant level. Adapted cells were obtained by shaking starved cells in $0.067 \mathrm{M}$-phosphate buffer $(\mathrm{pH} \mathrm{7 \cdot 2)}$ containing $0.003 \mathrm{M}-\mathrm{L}$-histidine at $30^{\circ}$ and following oxygen absorption in a pilot experiment until the rate became constant, after which the cells were washed and resuspended in phosphate buffer. Adapted cells were also produced by growth in the presence of L-histidine, either replacing ammonium chloride as sole nitrogen source, or replacing both glucose and ammonium chloride as sole sources of carbon and nitrogen in the basal medium described above. The L-histidine oxidizing capacity of cells grown in this way varied widely according to the age of culture from which the cells were harvested. Adapted cells retained their full activity for at least 6 days on storage at $-10^{\circ}$, though similar cells stored in the presence of chloramphenicol lost about $25 \%$ of their activity on storage for the same period.

Growth and dry weight content of suspensions were determined turbidimetrically in a Hilger absorptiometer, using a suitable calibration curve. Toluene-treated cells were obtained by adding a few drops of redistilled toluene to suspensions of induced

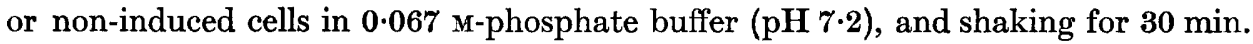
at $20^{\circ}$.

Cell-free enzyme preparations. Cell-free extracts were prepared by grinding a cell paste at $0^{\circ}$ with Microid Polishing Alumina (supplied by Griffin and Tatlock Ltd.), in a cooled glass mortar (McIlwain, 1948). The preparation was extracted with cold 0.067 M-phosphate buffer ( $\mathrm{pH} \mathrm{7 \cdot 2)}$ containing 0.001 M reduced gluthathione (GSH) and centrifuged at $5^{\circ}$ to remove unbroken cells, alumina particles and cell debris.

Chemical estimations. Ammonia was estimated by microdiffusion in Conway units (Conway, 1947), followed by nesslerization of the centre-well fluid, using the Nessler solution of Folin \& Denis (1916). The estimation of $\alpha$-amino nitrogen was carried out by measurement at $570 \mathrm{~m} \mu$ of the ninhydrin colour developed by the 
method of Moore \& Stein (1948), with L-histidine as standard. Histidine and glutamate were separated chromatographically, using $n$-butanol + acetic acid + water as solvent and $0.1 \%(\mathrm{w} / \mathrm{v})$ ninhydrin in $95 \%$ ethanol for the detection of the spots. L-Glutamate was estimated quantitatively by the glutamic acid decarboxylase of Clostridium welchii B.W. 21 (Epps, 1945; Gale, 1945). The quantitative estimation of urocanic acid was carried out by measurement of the absorption at $277 \mathrm{~m} \mu$ in a Unicam S.P. 500 spectrophotometer (Mehler \& Tabor, 1953).

Radioactivity was measured in a proportional gas flow (methane) counter, using ground glass planchettes. The thickness of samples was such that self absorption was negligible.

Enzyme assays. Histidase (histidine $\alpha$-deaminase, histidine deaminase) activity was determined by measurement of the urocanate formed at $30^{\circ}$ by cell-free extracts previously heated to $80^{\circ}$ for 15 min., followed by rapid cooling (Tabor \& Mehler, 1955). Routine estimations of the activity of cells towards L-histidine were made by measuring the rate of oxygen uptake in the presence of $0.003 \mathrm{M}-\mathrm{L}$-histidine in $0.067 \mathrm{M}$ phosphate buffer $\left(\mathrm{pH} \mathrm{7.2)}\right.$ at $30^{\circ}$, by conventional manometric methods. Comparisons between the rate of oxygen uptake by intact cells and the rate of ammonia production from L-histidine by cell-free extracts of partially induced cells suggested that measurements of oxygen uptake yielded valid estimates of the amounts of L-histidine degrading enzymes. This conclusion was supported by the observation that glutamate, an intermediate in L-histidine degradation, was rapidly oxidized at equal rates by both induced and non-induced cells, suggesting that changes associated with induction were confined to enzymes active exclusively in the conversion of L-histidine to glutamate, and not with the subsequent oxidation of the glutamate formed.

\section{RESULTS}

\section{The inducible nature of $\mathrm{L}-$ histidine oxidation}

Organisms grown in basal medium and then starved in $0.067 \mathrm{M}$-phosphate buffer (pH $7 \cdot 2$ ), exhibited a low rate of oxygen uptake on the addition of L-histidine. However, the rate of oxygen absorption increased until it reached a high and constant value in about $4 \mathrm{hr}$. (Fig. 1). Under these conditions the $Q_{0_{z}}$ increased from $c$. 7 to 50-55 and did not increase further in the presence of a higher initial L-histidine concentration or on the addition of a second quantity of the amino acid when oxidation of the first addition had ceased. Organisms grown in basal medium in which ammonium chloride was replaced by L-histidine ( $5 \mathrm{~g} . / 1$.$) , or in which both$ glucose and ammonium chloride were replaced by L-histidine as sole source of carbon and nitrogen exhibited a high rate of oxygen absorption immediately on the addition of L-histidine to washed organisms in $0.067 \mathrm{M}$-phosphate ( $\mathrm{pH} \mathrm{7 \cdot 2)}$ (Fig. 1).

Non-induced organisms grown in basal medium lacked the ability to oxidize urocanate but adaptation to L-histidine also imparted the ability to oxidize urocanate. Suspensions of starved organisms also acquired ability to degrade urocanate when shaken with 0.003 M-urocanate and were able to oxidize L-histidine. Urocanate was never oxidized as rapidly as L-histidine by organisms induced with L-histidine or urocanate, due possibly to the failure of urocanate to penetrate readily into the cell. Glutamate was oxidized rapidly and at equal rates by unadapted organisms and by organisms exposed to either L-histidine or urocanate. 
Effect of inhibitors. Addition of $2.0 \times 10^{-4} \mathrm{M}-2: 4$-dinitrophenol, $4.0 \times 10^{-3} \mathrm{M}$ sodium azide, $5 \cdot 0 \times 10^{-3} \mathrm{M}$-DL- $p$-fluorophenylalanine or $5 \cdot 0 \times 10^{-2} \mathrm{M} \beta$-2-L-thienylalanine to non-induced organisms in presence of $\mathrm{L}$-histidine under conditions described above, completely suppressed the adaptive response. The separate addition of 5-bromouracil, 6-amino-2-mercaptopurine sulphate, 2:6-diamino-purine sulphate or 5-fluorouracil, all at a concentration of $500 \mu \mathrm{g} . / \mathrm{ml}$., were without effect on the course of induction. At the same concentration 8-azaguanine was slightly inhibitory.

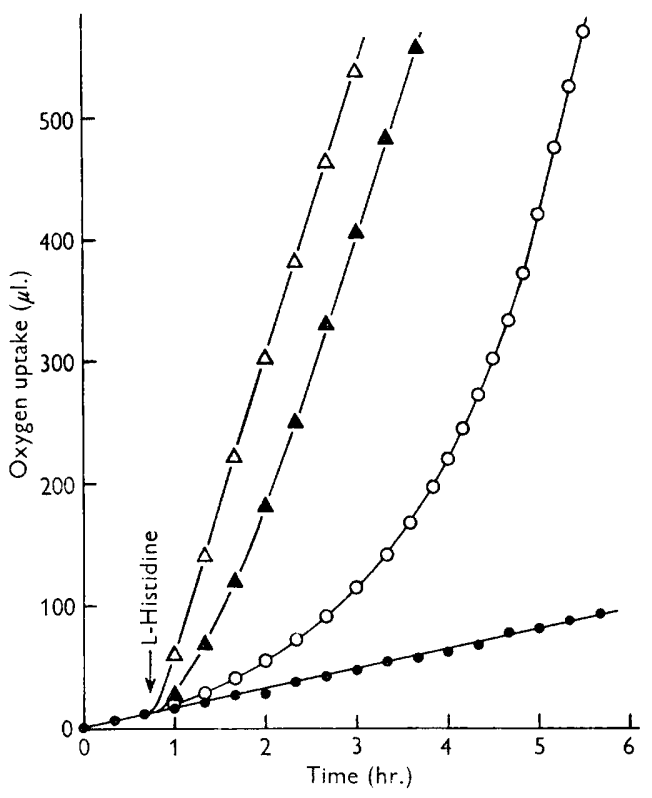

Fig. 1

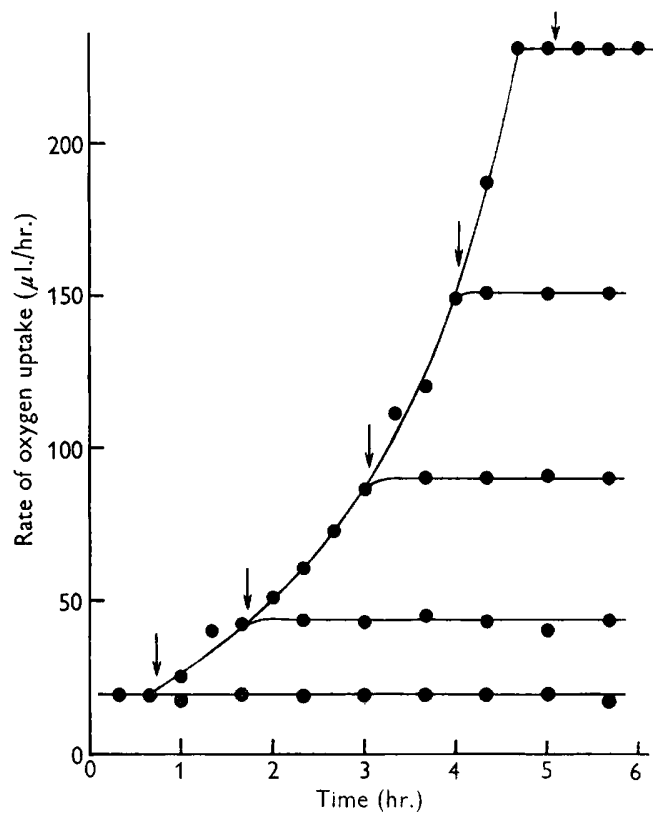

Fig. 2

Fig. 1. The effect of addition of $0.003 \mathrm{M}-\mathrm{L}$-histidine on the oxygen uptake of cells grown in basal medium $(O)$; basal medium containing L-histidine as sole source of nitrogen $(\Delta)$; basal medium containing L-histidine as sole sources of carbon and nitrogen $(\triangle)$. Endogenous oxygen uptake of cells grown in basal medium (๑). Warburg flasks contained $4 \mathrm{mg}$. dry wt. cells suspended in 0.067 $\mathrm{M}$-phosphate buffer, pH 7.2.

Fig. 2. Effect of chloramphenicol on the rate of oxygen uptake in the presence of L-histidine. Two-arm Warburg flasks containing: (m.c.) $2 \mathrm{ml}$. suspension of non-induced cells $(2 \mathrm{mg}$. dry wt. cells $/ \mathrm{ml}$.) in $0.067 \mathrm{M}$ phosphate buffer, $\mathrm{pH} 7 \cdot 2 ;(s . b .1) 0.3 \mathrm{ml} .0 .033 \mathrm{M}$ L-histidine; (s.b. 2) $0.2 \mathrm{ml}$. chloramphenicol solution $(625 \mu \mathrm{g} . / \mathrm{ml}$.); (c.w.) $0.2 \mathrm{ml} .10 \%$ (w/v) KOH. L-Histidine added to all flasks after $40 \mathrm{~min}$. Chloramphenicol added at times indicated by arrows.

The adaptive response of non-induced organisms to L-histidine was prevented by chloramphenicol at a concentration of $5 \mu \mathrm{g} . / \mathrm{ml}$., whereas $1000 \mu \mathrm{g} . / \mathrm{ml}$. did not inhibit the oxidation of L-histidine by induced organisms. Addition of chloramphenicol (50 $\mu \mathrm{g} . / \mathrm{ml}$.) during the course of induction resulted in oxygen absorption continuing linearly at the rate reached at the moment of addition of the inhibitor (Fig. 2). Chloramphenicol was accordingly used for the prevention of further enzyme synthesis during the experiments to be described below.

Presence of a permeability barrier or enzyme inhibitor in non-induced cells. The 
effect of inhibitors suggests the synthesis of enzyme protein (or proteins) was involved during adaptation to L-histidine, though synthesis of a protein component of a transport mechanism responsible for the penetration of L-histidine into the cells might be involved. Cell-free extracts of induced cells, or toluene-treated induced cells, produced glutamate and ammonia from L-histidine, whereas similar treatment of non-induced cells yielded almost inactive preparations (Table 1). Preparations of non-induced cells produce small amounts of ammonia and glutamate owing to the presence of 'basal' enzymes in such cells.

\title{
Table 1. Production of ammonia and glutamate from L-histidine by extracts and toluene-treated induced and non-induced organisms
}

\begin{abstract}
Incubation mixtures consisted of cell extract in $0.067 \mathrm{M}$-phosphate buffer (pH $7 \cdot 2$ ), containing 0.001 $\mathrm{m}$-GSH or toluene-treated cell suspension ( $5 \mathrm{mg}$. dry wt. $/ \mathrm{ml}$.) in $0.067 \mathrm{~m}$ phosphate buffer $(\mathrm{pH} 7 \cdot 2)$, together with $6.0 \mu$ mole. L-histidine $/ \mathrm{ml}$. Incubation at $30^{\circ}$ for $2 \mathrm{hr}$. (toluene-treated cells) or for $3 \mathrm{hr}$. (cell-free extracts). All figures corrected for blank values obtained from control preparations without added L-histidine.
\end{abstract}

\begin{tabular}{|c|c|c|c|c|}
\hline & & $\begin{array}{c}\text { Residual } \\
\text { L-histidine } \\
(\mu \text { mole./ml. })\end{array}$ & $\begin{array}{c}\text { Ammonia } \\
\text { formed } \\
(\mu \text { mole. } / \mathrm{ml} .)\end{array}$ & $\begin{array}{c}\text { L-Glutamate } \\
\text { formed } \\
(\mu \text { mole. } / \mathrm{ml} .)\end{array}$ \\
\hline Cell extracts & $\left\{\begin{array}{l}\text { induced cells } \\
\text { non-induced cells }\end{array}\right.$ & $\begin{array}{l}1 \cdot 8 \\
5 \cdot 7\end{array}$ & $\begin{array}{l}8 \cdot 1 \\
0 \cdot 2\end{array}$ & $\begin{array}{c}\mathbf{3 . 9} \\
\text { Trace* }\end{array}$ \\
\hline Toluene-treated cells & $\left\{\begin{array}{l}\text { induced cells } \\
\text { non-induced cells }\end{array}\right.$ & $\begin{array}{l}0 \\
5 \cdot 5\end{array}$ & $\begin{array}{r}11 \cdot 8 \\
0 \cdot 8\end{array}$ & $\begin{array}{c}5 \cdot 9 \\
\text { Trace* }\end{array}$ \\
\hline
\end{tabular}

* Preparations from non-induced cells produced insufficient L-glutamate to estimate by the decarboxylase method, but a trace of glutamate was detected chromatographically.

The possibility that non-induced cells possess the enzymes responsible for L-histidine degradation but contain an inhibitor which is in some way removed on the addition of inducer, appeared unlikely since the addition of a cell-free extract of non-induced cells had no inhibitory effect on the production of ammonia from L-histidine by a cell-free extract of induced cells.

The occurrence of 'basal' enzyme in non-induced cells. The addition of chloramphenicol to thick suspensions of non-induced cells was without significant effect on the rate of endogenous respiration, but the further addition of L-histidine resulted in a slight, but reproducible, stimulation of oxygen uptake (Table 3). This observation, under conditions where enzyme synthesis was prevented by chloramphenicol, suggests the presence of some 'basal' enzyme in non-induced cells. The oxidation of L-histidine by induced cells results in the formation of $\mathrm{CO}_{2}$. Exposure of noninduced cells to (2-ring- $\left.{ }^{14} \mathrm{C}\right)$-L-histidine in the presence of chloramphenicol resulted in the appearance of ${ }^{14} \mathrm{CO}_{2}$ in the respiratory $\mathrm{CO}_{2}$ (Fig. 3). Thus non-induced cells under conditions precluding induced enzyme synthesis possessed the capacity to liberate the $\mathrm{C}-2$ of the imidazole ring as $\mathrm{CO}_{2}$. The rate of liberation of ${ }^{14} \mathrm{CO}_{2}$ was equivalent to 2533 counts/min./flask/hr. A suspension of fully induced cells of similar cell density liberated 125,685 counts/min./flask/hr. From these values the 'basal' enzymes in non-induced cells are present to the extent of $c .2 \%$ of the values found in fully induced cells.

Figure 3 also shows that there was no lag in the liberation of ${ }^{14} \mathrm{CO}_{2}$ from 
(2-ring- ${ }^{14} \mathrm{C}$ )-L-histidine, an observation which supports the view that non-induced cells are permeable to L-histidine, without the prior synthesis of a transport mechanism (or permease).

\section{The ability of imidazoles to act as inducing substances}

A variety of imidazoles other than L-histidine were tested for their ability to induce the formation of enzymes responsible for the degradation of L-histidine. Suspensions of non-induced cells were exposed to compounds for $4 \mathrm{hr}$., further enzyme synthesis being prevented by the addition of chloramphenicol. After washing and resuspending the cells in $0.067 \mathrm{M}$-phosphate buffer $(\mathrm{pH} 7 \cdot 2)$ containing chloramphenicol (50 $\mu \mathrm{g}$. $/ \mathrm{ml}$.), the ability of suspensions to oxidize L-histidine was measured

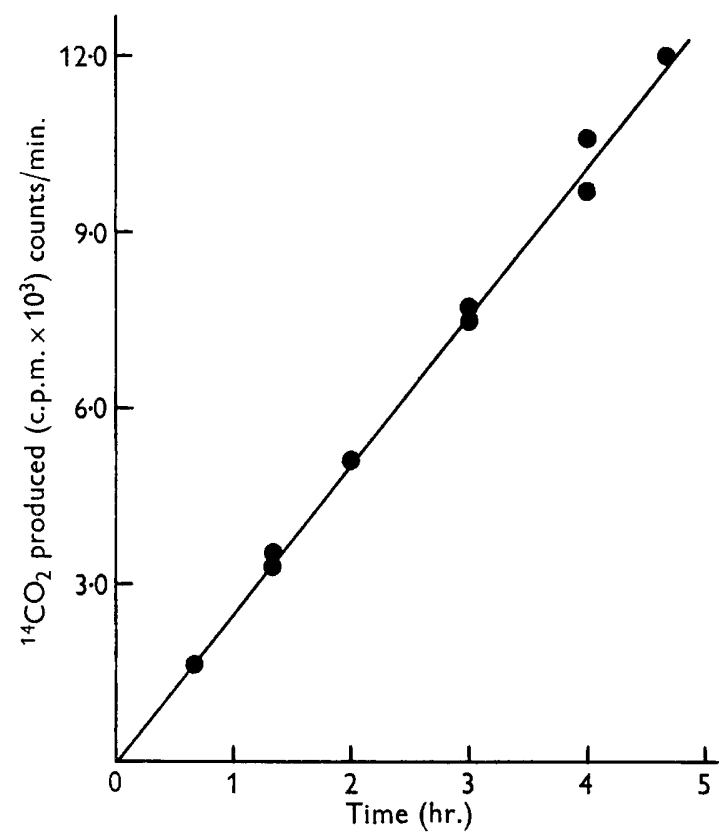

Fig. 3. Liberation of $\left[{ }^{14} \mathrm{C}\right]$ carbon dioxide from [2-ring- $\left.{ }^{14} \mathrm{C}\right]-\mathrm{L}$-histidine by non-induced cells. Two-arm Warburg flasks contained: (m.c.) 2 ml. cell suspension (3.8 mg. dry wt. $/ \mathrm{ml}$.) in $0.067 \mathrm{M}$-phosphate (pH 7.2); $0.2 \mathrm{ml}$. chloramphenicol solution $(625 \mu \mathrm{g} . / \mathrm{ml}) ;.(s . b .1)$ $0.3 \mathrm{ml}$. 0.033 M $\left[2\right.$-ring- $\left.{ }^{14} \mathrm{C}\right]-\mathrm{L}$-histidine $(264,300$ counts $/ \mathrm{min}$./flask); (s.b. 2) $0.2 \mathrm{ml}$. $5 \mathrm{~N}-\mathrm{H}_{2} \mathrm{SO}_{4}$ added to stop the reaction and to liberate any $\mathrm{CO}_{2}$ bound by the phosphate buffer; (c.w.) $0.2 \mathrm{ml} .10 \%(\mathrm{w} / \mathrm{v}) \mathrm{KOH}$. Radioactivity of $\mathrm{CO}_{2}$ produced was estimated by quantitative removal of centre well fluid and counting as $\mathrm{K}_{2} \mathrm{CO}_{3}$.

by determining the rate of oxygen uptake in the presence of L-histidine. Examination of the results of such an experiment (Table 2) reveals that urocanic acid, Dhistidine, L-histidyl-L-histidine and $\beta$-alanyl-L-histidine were capable of acting as inducers, whereas a variety of other imidazoles were devoid of activity. The single pyrazole tested, namely $\beta$-(pyrazolyl-3)-alanine was unable to induce the synthesis of L-histidine degrading enzymes. The enzyme activities induced in the presence of L-histidyl-L-histidine, $\beta$-alanyl-L-histidine, urocanate and D-histidine were in all instances considerably lower than that induced by an identical molar concentration 
of L-histidine. It appeared likely that induction by the two dipeptides was due to hydrolysis to free histidine, but this point was not investigated further.

The possibility that induction by $\mathrm{D}$-histidine was due to contamination by the L-isomer was prevented by using a preparation of the $D$-isomer freed of L-histidine by previously shaking an aqueous solution of commercial $D$-histidine with a thick suspension of fully induced organisms for $1 \mathrm{hr}$. to destroy any L-histidine, followed by centrifugation and precipitation of the $\mathrm{D}$-isomer by addition of absolute ethanol. This product did not support the growth of Streptococcus faecalis $R$ or Leuconostoc mesenteroides $\mathrm{P}-60$ in media suitable for the micro-biological assay of L-histidine (Henderson \& Snell, 1948).

\title{
Table 2. The ability of various imidazoles to induce the formation of L-histidine degrading enzymes
}

\begin{abstract}
Incubation mixtures contained $10 \mathrm{ml}$. cell suspension (2 mg. dry wt. $/ \mathrm{ml}$.) in $0.067 \mathrm{M}-$ phosphate buffer ( $\mathrm{pH} \mathrm{7.2)}$ and $0.003 \mathrm{M}$-inducing substance. After shaking $4 \mathrm{hr}$. at $30^{\circ}$ chloramphenicol added to $50 \mu \mathrm{g}$. $/ \mathrm{ml}$.; cells washed with 0.067 M-phosphate buffer (pH 7.2) containing $50 \mu \mathrm{g} . / \mathrm{ml}$. chloramphenicol and resuspended in the same solution. The amount of enzyme(s) synthesized measured as the rate of oxygen uptake in the presence of $0.003 \mathrm{M}-\mathrm{L}$-histidine. The endogenous respiration rate (27 $\mu \mathrm{l} . \mathrm{O}_{2}$ absorbed/hr.)
\end{abstract} has been subtracted from all values.

\begin{tabular}{lrlr}
\multicolumn{1}{c}{ Addition } & $\mu \mathrm{l} . \mathrm{O}_{2} / \mathrm{hr}$. & \multicolumn{1}{c}{ Addition } & $\mu \mathrm{l} . \mathrm{O}_{2} / \mathrm{hr}$. \\
L-Histidine & 205 & 4:5-Imidazole dicarboxylic acid & 6 \\
Urocanic acid & $\mathbf{1 3 6}$ & Imidazole & 5 \\
D-Histidine & $\mathbf{9 3}$ & Histamine & -1 \\
L-Histidyl-L-histidine & 95 & $\beta$-(Pyrazolyl-3)alanine & 3 \\
$\beta$-Alanyl-L-histidine & 88 & None & 4 \\
Benzimidazole & 8 & &
\end{tabular}

\section{Metabolism of D-histidine}

The use of thick suspensions of non-induced organisms revealed a higher rate of oxygen uptake in the presence of $D$-histidine compared with the endogenous respiration rate. The further addition of chloramphenicol to suppress enzyme synthesis in presence of $D$-histidine resulted in a decrease in the rate of oxygen uptake to a value very close to the endogenous rate (Table 3). There is good evidence that the respiration rate of many systems is controlled by the concentration of phosphate acceptors and since the addition of $\mathrm{D}$-histidine initiates enzyme synthesis this may increase the concentration of phosphate acceptors and hence increase the rate of respiration (Chance \& Williams, 1956). The addition of $\mathrm{D}$-histidine to induced organisms resulted in significant stimulation of the rate of oxygen uptake compared with the rate observed in control organisms. Further addition of chloramphenicol had little or no effect (Table 3). Comparison of rates of oxygen uptake by induced organisms in presence of $\mathrm{D}$ - or $\mathrm{L}$-histidine reveals that, after subtraction of the endogenous rate of oxygen absorption, the rate of oxidation of the D-isomer was about $10 \%$ of the $\mathrm{L}$-histidine oxidation rate; $\mathrm{D}$-histidine did not inhibit the oxidation of $\mathrm{L}$-histidine by induced organisms at $\mathrm{D}: \mathrm{L}$ ratios as high as $25: 1$.

The formation of ammonia from $\mathrm{L}$ - and $\mathrm{D}$-histidine by thick suspensions of intact induced organisms and toluene-treated induced organisms is shown in Fig. 4. Ammonia production from the $\mathrm{D}$-isomer was considerably less than from L-histidine. 
The addition of L-histidine to toluene-treated induced organisms resulted in the accumulation of virtually quantitative amounts of glutamate (Table 1 and Fig. 4). In several experiments involving the addition of the $\mathbf{D}$-isomer to such organisms no significant glutamate production was detected above the trace amounts found chromatographically in control organisms to which water had been added.

Extracts of induced organisms yielded ammonia from L-histidine, but not from the D-isomer (Fig. 5). Tabor \& Mehler (1955) showed that urocanase activity of extracts of Pseudomonas fuorescens could be eliminated by heating the cell-free extract to $80^{\circ}$ for $15 \mathrm{~min}$. The histidase activity of heated extracts was unimpaired and resulted in the accumulation of urocanate from L-histidine. Figure 5 shows that

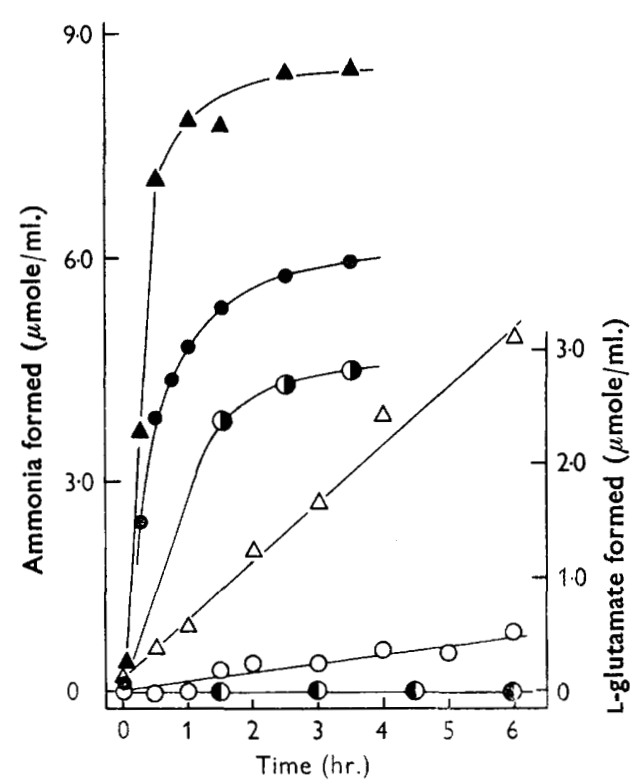

Fig. 4

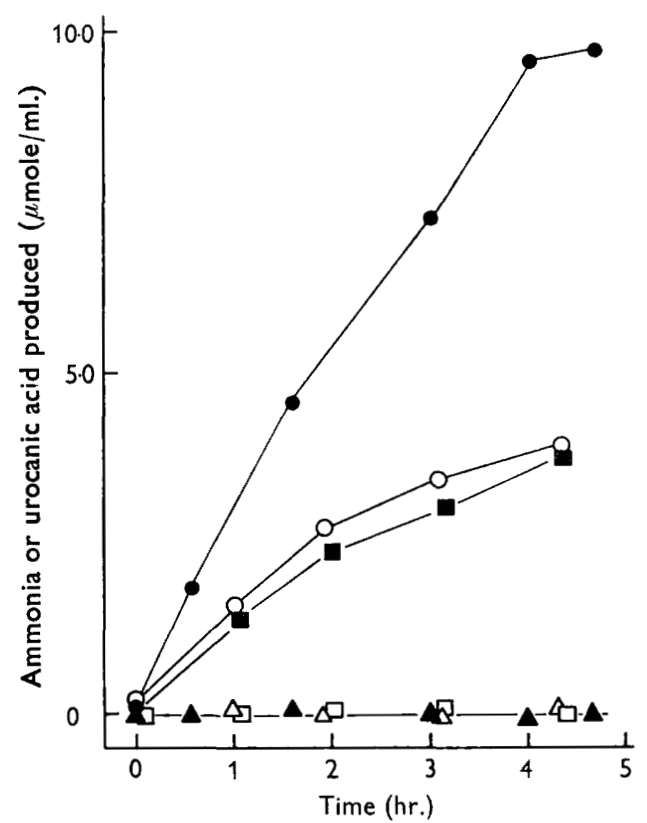

Fig. 5

Fig. 4. Production of ammonia and L-glutamate by intact and toluene-treated induced cells. Incubation mixtures, contained in $250 \mathrm{ml}$. Erlenmeyer flasks shaken at $30^{\circ}$, consisted of intact or toluene-treated cell suspensions $(7 \cdot 3 \mathrm{mg}$. dry wt. cells/ml.) in 0.067 M-phosphate ( $\mathrm{pH} \mathrm{7 \cdot 2)}$ to which $3 \mu$ mole $\mathrm{L}$ - or $\mathrm{D}$-histidine $/ \mathrm{ml}$. was added at $0 \mathrm{hr}$. Intact cells : $\Delta-\Delta$, ammonia production in the presence of $\mathrm{L}$-histidine ; $\triangle-\triangle$, ammonia production in the presence of $\mathrm{D}$-histidine. Toluene-treated cells : - - ammonia production in the presence of $\mathrm{L}$-histidine; $\mathrm{O}-\mathrm{O}$, ammonia production in the presence of $D$-histidine; $-O$, glutamate production in the presence of L-histidine; $D-D$, glutamate production in the presence of $\mathbf{D}$-histidine. All values corrected for control flasks containing an equivalent volume of water in place of $L$ - or $D$-histidine solution.

Fig. 5. Production of ammonia and urocanate by extracts and heated extracts of induced cells. Incubation mixtures, maintained at $30^{\circ}$, consisted of cell extract or

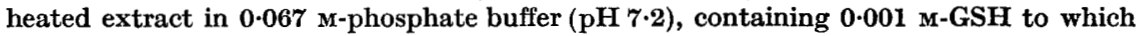
$5 \mu$ mole. $\mathrm{L}$ - or $\mathrm{D}$-histidine was added at $0 \mathrm{hr}$. Cell extract: - - , ammonia production in the presence of $\mathrm{L}$-histidine; $\Delta-\Delta$ ammonia production in the presence of $\mathrm{D}$-histidine. Heated cell extract: $O-O$, ammonia production in the presence of $L$-histidine; $\triangle-\triangle$, ammonia production in the presence of $D$-histidine; $\square-\square$, urocanate production in the presence of L-histidine; $\square-\square$, urocanate production in the presence of $\mathrm{D}$-histidine. All values corrected for control extracts containing an equivalent volume of water in place of $\mathrm{L}$ - or D-histidine solution. 
heated extracts of organism 232 also produced ammonia and urocanate from L-histidine, but no increase in either ammonia or urocanate could be detected in the presence of $\mathrm{D}$-histidine. Thus $\mathrm{D}$-histidine was apparently metabolized by the organism studied, though the rate of metabolism was very much slower than that of the L-isomer. Furthermore, the failure to demonstrate ammonia and urocanate formation from $D$-histidine by extracts able to produce both these substances from L-histidine suggests that the oxygen absorption observed when the $\mathrm{D}$-isomer was added to induced organisms was the result of a different metabolic pathway from that responsible for the degradation of L-histidine.

Table 3. Rates of oxygen uptake by induced and non-induced organisms in the presence of $\mathrm{L}$-histidine, $\mathrm{D}$-histidine and chloramphenicol

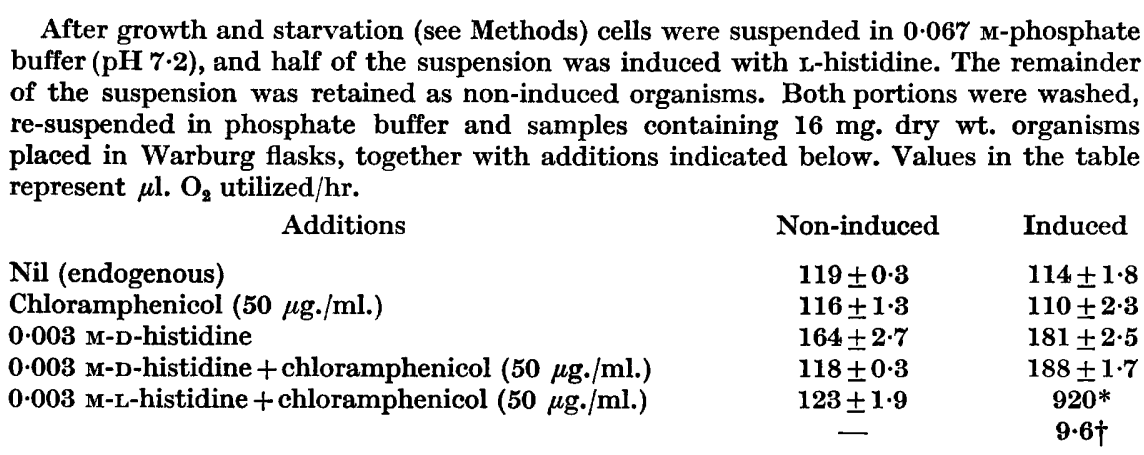

Figures represent the mean \pm standard error of the mean, based on 4 determinations.

* Values obtained by calculation from suspensions of induced organisms diluted with 0.067 Mphosphate buffer, $\mathrm{pH} \mathbf{7 \cdot 2}$.

$\dagger$ Rate of oxidation of $D$-histidine expressed as percentage of the rate of oxidation of L-histidine, after correction for the endogenous oxygen absorption.

\section{The kinetics of induction}

The kinetics of induction, together with the factors affecting the induction process, were studied by taking samples of organisms exposed to inducer into centrifuge tubes containing chloramphenicol solution to give a final concentration of $50 \mu \mathrm{g}$. chloramphenicol/ml., centrifuging, washing and resuspending the organisms in sufficient $0.067 \mathrm{M}$-phosphate buffer ( $\mathrm{pH} \mathrm{7.2)}$ ) containing chloramphenicol to give $2 \mathrm{mg}$. dry wt. cells/ml. suspension. The amount of induced enzyme or enzymes synthesized was measured by the determination of the rate of oxygen uptake by $2 \mathrm{ml}$. samples of these washed suspensions in the presence of $0.003 \mathrm{M}-\mathrm{L}$-histidine.

Induction by L-histidine. The kinetics of enzyme induction in a washed cell population exposed to L-histidine is shown in Fig. 6. Increasing the initial concentration of the inducer from $0.003 \mathrm{M}$ - to $0.01 \mathrm{M}$-L-histidine did not affect the maximal level of enzymic activity, but delayed the onset of the subsequent decrease in activity, which was correlated with the disappearance of the inducer.

Induction by $\mathrm{D}$-histidine. When $\mathrm{D}$-histidine was added to a washed suspension of the organism enzymes capable of degrading the L-isomer were formed, but the kinetics of the induction differed from those observed when L-histidine was used as the inducing agent. Enzyme production was linear and the maximum enzyme value was 
not reached until 6-7 hr. after addition of the inducer (Fig. 7). Furthermore, the final enzyme value attained was lower than that reached by organisms induced with L-isomer and was stable for at least $12 \mathrm{hr}$. This stability was shown to be due to continued presence of $\mathrm{D}$-histidine, whereas under the conditions of the experiments induction by L-histidine was followed by a 'decay' of enzyme activity following the rapid exhaustion of the inducer. Within the limits of accuracy of the method used for measurement of enzyme activity the formation of enzyme commenced immediately on the addition of inducer.

Organisms induced with $\mathbf{D}$-histidine oxidized not only L-histidine, but also urocanic acid. In a typical experiment a suspension of organisms induced with D-histidine oxidized L-isomer at a rate equivalent to the uptake of $90 \mu \mathrm{l} . \mathrm{O}_{2} / \mathrm{hr}$. and in the presence of urocanate a sample of the same suspension used $63 \mu \mathrm{l} . \mathrm{O}_{2} / \mathrm{hr}$. The significance of

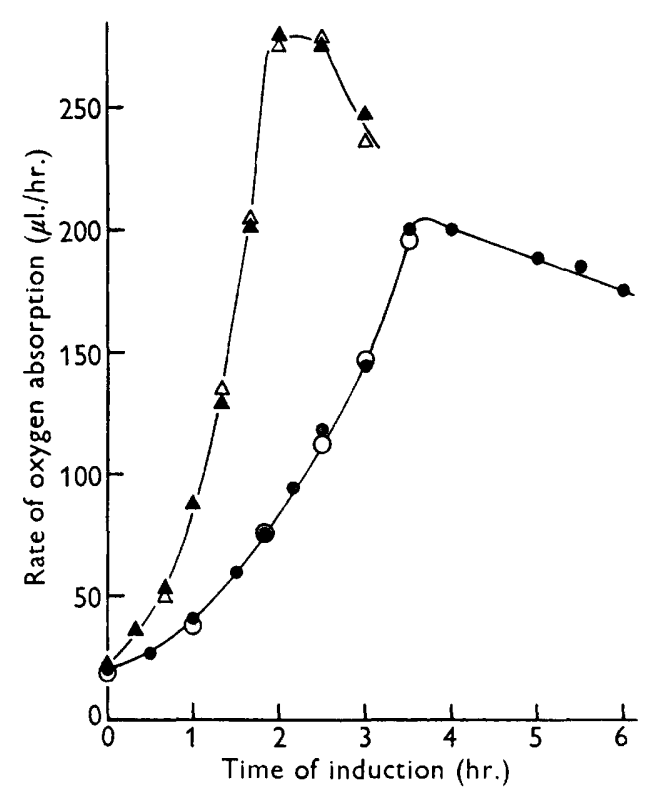

Fig. 6

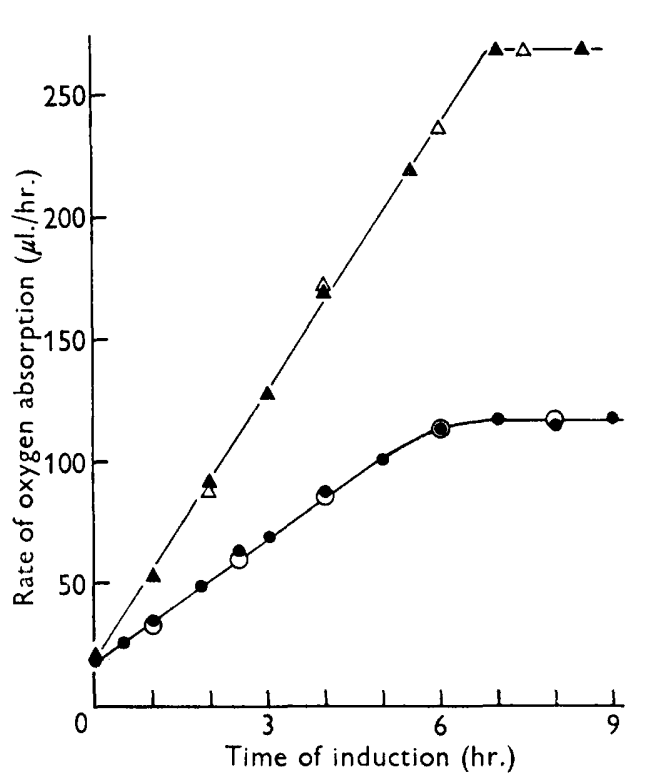

Fig. 7

Fig. 6. The induction of L-histidine degrading enzymes by L-histidine in the presence and absence of sodium succinate and ammonium chloride. Induction mixtures consisted of $120 \mathrm{ml}$. of cell suspension ( $2 \mathrm{mg}$. dry wt. cells $/ \mathrm{ml}$.) in $\mathbf{0 . 0 6 7} \mathrm{M}$-phosphate buffer $(\mathrm{pH} 7 \cdot 2) ;(\bullet)$; cell suspension + $0.02 \mathrm{M}$ sodium succinate $(\Delta)$; cell suspension + ammonium chloride (100 $\mu \mathrm{g} . / \mathrm{ml}$.) (O); cell suspension +0.02 M-sodium succinate + ammonium chloride $(100 \mu \mathrm{g} . / \mathrm{ml}$.) $(\triangle)$. All flasks received, as inducer, $0.003 \mathrm{M}-\mathrm{L}$-histidine at $0 \mathrm{hr}$. At intervals $8.0 \mathrm{ml}$. samples were withdrawn into centrifuge tubes containing sufficient chloramphenicol solution, to give a final concentration of $50 \mu \mathrm{g}$. chloramphenicol $/ \mathrm{ml}$. After washing in 0.067 $\mathrm{m}$-phosphate buffer (pH 7.2) containing $50 \mu \mathrm{g}$. chloramphenicol $/ \mathrm{ml}$. the pellets were resuspended in the same solution to give $2 \mathrm{mg}$. dry wt. cells $/ \mathrm{ml}$. and duplicate $2 \mathrm{ml}$. samples placed in Warburg flasks. Enzyme synthesis was measured as the rate of oxygen uptake in the presence of $0.003 \mathrm{M}-\mathrm{L}$-histidine. Endogenous respiration rates were obtained from a Warburg flask containing water in place of L-histidine. Each point represents the average of duplicate determinations. Endogenous respiration rate (23 $\mu$ l. $\mathrm{O}_{2} / \mathrm{hr}$.) not subtracted.

Fig. 7. The induction of $\mathrm{L}$-histidine degrading enzymes by $\mathrm{D}$-histidine in the presence and absence of sodium succinate and ammonium chloride. Details and symbols as in Fig. 6, except that induction was accomplished with $0.003 \mathrm{M}-\mathrm{D}$-histidine. 
this observation will be discussed later (see Discussion). In all experiments described the initial inducer concentration was $3 \cdot 33 \mu \mathrm{mole} . / \mathrm{ml}$. Under the conditions outlined above, using D-histidine as inducer, the induction mechanism appeared to be saturated and the maximum rate of enzyme synthesis achieved at a concentration of $\mathbf{2} \cdot \mathbf{0} \mu$ mole, $\mathbf{D}$-histidine $/ \mathrm{ml}$.

The effect of succinate and ammonium chloride on induction. The difference in final enzyme values after induction with $L$ - and $D$-histidine (Figs. 6 and 7 ) was consistently observed in a number of experiments.

This difference may be accounted for by exhaustion of endogenously available nitrogen sources, respiratory substrate, carbon for synthetic purposes (or a combination of these factors) in organisms induced with $D$-histidine, whereas in those induced with the $\mathrm{L}$-isomer these reserves may be replenished from the products of $L$-histidine degradation. The effects of adding 0.02 M-sodium succinate and ammonium chloride $(100 \mu \mathrm{g} . / \mathrm{ml}$.) on the development of induced enzyme activity, with $\mathrm{L}$ - and $\mathrm{D}$-histidine as inducers are shown in Figs. 6 and 7. Addition of succinate resulted in an increase in the rate of enzyme formation and the final values of enzymic activity attained was higher than the corresponding maxima observed in the absence of succinate. Furthermore, in the presence of succinate, induction by $D$-histidine led to a final enzymic activity identical with that observed when organisms were induced by L-isomer. The addition of ammonium chloride (100 $\mu \mathrm{g} . / \mathrm{ml}$.) was without effect on either the rate or final value of enzyme production whether organisms were induced with L- or D-histidine, either in the presence or absence of succinate.

\section{Table 4. Effect of nitrogen starvation on synthesis of L-histidine degrading enzymes}

Nitrogen-starved organisms prepared as described in the text were suspended in

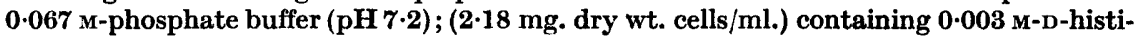
dine. After induction for periods indicated below, during which flasks were shaken at $30^{\circ}$, chloramphenicol (50 $\mu \mathrm{g}$. $/ \mathrm{ml}$.) added and organisms washed in $0.067 \mathrm{M}$-phosphate ( $\mathrm{pH} 7 \cdot 2)$ containing $50 \mu \mathrm{g}$. chloramphenicol $/ \mathrm{ml}$. and resuspended in the same solution. Enzyme synthesis was measured as the rate of oxygen uptake in the presence of $0.003 \mathrm{M}$-L-histidine. Results expressed as $\mu$ l. oxygen utilized $/ \mathrm{hr}$.

$\overbrace{0}^{\text {Time of induction (hr.) }}$

Type I organisms : shaking in nitrogen-free and nitrogen-rich medium after growth in normal medium

$\begin{array}{lllr}\text { Nitrogen-deficient } & 41(-1) & 69(33) & 95(62) \\ \text { Nitrogen-rich } & 31(0) & 81(46) & 116(83)\end{array}$

Type II organisms : growth in nitrogen-deficient and nitrogen-rich medium

$\begin{array}{llll}\text { Nitrogen-deficient } & 38(2) & 48(19) & 62(39) \\ \text { Nitrogen-rich } & 29(3) & 84(60) & 97(73)\end{array}$

Figures in parentheses represent values corrected for endogenous respiration rates.

\section{The effect of nitrogen starvation}

Nitrogen-starved organisms were obtained in two ways. Type I organisms were harvested after growth in normal medium, washed and resuspended aseptically in normal medium from which the nitrogen source was omitted, and shaken for $6 \mathrm{hr}$. at $30^{\circ}$. Control organisms were resuspended in medium containing normal amounts of ammonium chloride (see Methods). Type II organisms were obtained by growth 
organisms in medium containing a limiting amount of ammonium chloride (300 mg./1 medium). Growth ceased due to the exhaustion of nitrogen supply and enzyme synthesis by these organisms was compared with control cells grown on normal medium. On addition of D-histidine both Type I organisms and Type II organisms were able to synthesize induced enzyme, though after a $6 \mathrm{hr}$. induction period Type I organisms had only $75 \%$ of the activity of 'normal' ones and Type II organisms developed enzyme equivalent to $53 \%$ of that of 'normal' organisms (Table 4). The endogenous rates of respiration of both types of nitrogen-starved organisms was high, presumably due to assimilation of carbon from the medium in the absence of exogenous nitrogen sources.

\section{DISCUSSION}

The synthesis of histidase and urocanase (and possibly other enzymes involved in the conversion of L-histidine to glutamate) has been shown to be inducible in Paracolobactrum aerogenoides (strain 232). The adaptive pattern in this organism closely resembles that described in a pseudomonad (Suda et al. 1952). The formation of urocanate, glutamate and ammonia by extracts of induced organisms and toluene-treated organisms (Figs. 4 and 5) suggests that the pathway of L-histidine degradation is similar to that observed in Pseudomonas fluorescens and Aerobacter aerogenes (Tabor, 1955; Magasanik \& Bowser, 1955).

Competent inducers, structurally related to the substrates of induced enzymes, though incapable of acting as substrates have been described for a variety of bacterial systems (Monod, Cohen-Bazire \& Cohn, 1951; Buttin, Cohen-Bazire \& Monod, 1956; Duerksen \& Halvorson, 1959). The failure to detect urocanate and glutamate formation from $D$-histidine by extracts of organism 232 supports the view that the $\mathrm{D}$-isomer is behaving as a 'non-metabolizable' inducer. Addition of $\mathrm{D}$ histidine to fully induced organisms does, however, lead to slight stimulation of the rate of oxygen uptake and ammonia production (Table 3 and Fig. 4).

Kallio \& Larson (1955), studying the methionine racemase of a pseudomonad, and Gunsalus, Stanier \& Gunsalus (1953), studying the mandelic acid racemase of Pseudomonas fluorescens, described the induction by the D-isomer of an enzyme attacking the corresponding L-isomer. Both these racemases differ from the histidine oxidation system since both isomers are substrates and are attacked at comparable rates. Shilo (1957) and Shilo \& Stanier (1957) described a strain of soil pseudomonad capable of forming three stereospecific dehydrases active against $d$-, $l$ - and meso-tartrates (see Shilo loc. cit. for configurational notation). The induction of each dehydrase was also highly stereospecific, so that only the isomer on which the organism had been grown was oxidized without a lag. La Rivière (1956) recorded similar observations with $P$. putida, but a situation at variance with these results has been described (Martin \& Foster, 1957).

The induction pattern exhibited by $D$-histidine in our Paracolobactrum may be explained by the slow conversion of the $\mathrm{D}$-histidine to the $\mathrm{L}$-isomer, followed by sequential induction of urocanase by the urocanate produced from L-histidine by the action of histidase. Alternatively, since urocanate induces the formation of both histidase and urocanase, the conversion of D-histidine to urocanate by histidase would account for the experimental observations. This explanation seems unlikely, since the available evidence suggests that histidase does not attack the D-isomer. 
Lastly both isomers of histidine, together with urocanate, may be converted to a compound which is responsible for the actual induction of the enzymes, or the induction site may be characterized by relatively poor specificity and capable of being activated by both isomers of histidine and by urocanate.

Three possible mechanisms by which D-histidine may be converted to the L-isomer may be discussed. First, the organisms may contain a histidine racemase comparable with the alanine racemase of Streptococcus faecalis and other bacteria (Wood \& Gunsalus, 1951; Stewart \& Halvorson, 1953; Marr \& Wilson, 1954), the methionine racemase of a pseudomonad (Kallio \& Larson, 1955) or the glutamate racemase of Lactobacillus arabinosus (Narrod \& Wood, 1952). Secondly, D-histidine may be attacked by a $\mathrm{D}$-amino acid oxidase, yielding $\beta$-imidazole pyruvate which, by transamination, could yield L-histidine. Finally, the $\mathrm{D}$-isomer may be converted to the L-isomer by the successive actions of a D-amino acid transaminase, alanine racemase and L-amino acid transaminase as follows:

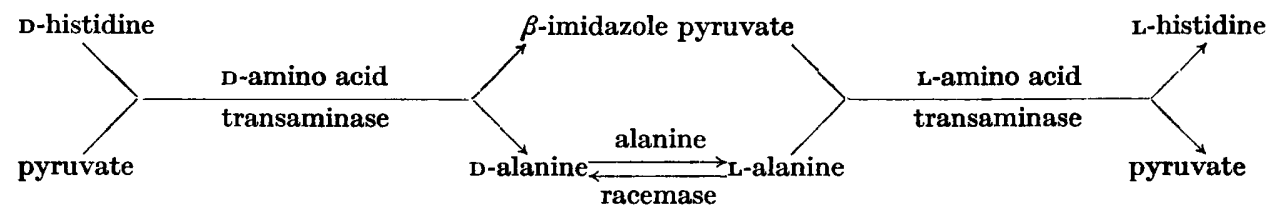

Thorne \& Molnar (1955) demonstrated in some members of the genus Bacillus the presence of one or more enzymes capable of catalysing transaminations between pyruvate and some $\mathrm{D}$-amino acids, including $\mathrm{D}$-histidine. That $\mathrm{D}$-histidine can be inverted in the animal body was demonstrated by Conrad \& Berg (1937) who studied the growth of rats (for which histidine is an essential amino acid) on a diet containing the D-isomer as source of histidine. Analysis of carcasses showed an increase in histidine content and the histidine isolated was virtually pure L-histidine. Reviewing the utilization of D-amino acids by animals Berg (1959) suggested that the mechanism of this inversion consists of conversion to the $\alpha$-keto analogue followed by re-amination by transamination.

Extracts of paracolobactrum 232, heat-treated to destroy urocanase activity (Tabor \& Mehler, 1955), produced ammonia and urocanate from L-histidine, but no detectable amounts from the D-isomer (Fig. 5), and suggesting that the histidase of this organism is inactive against $D$-histidine. This observation is in agreement with that of Edlbacher \& Kraus (1930) who stated that D-histidine is not attacked by animal histidase. These observations suggest that the $\mathrm{D}$-isomer is metabolized by a route different from that of L-histidine, but do not exclude the possibility of the occurrence of a histidine racemase since this enzyme may be labile to the extraction procedures used, or more especially to the heat treatment necessary for the destruction of urocanase activity. The oxygen absorption and ammonia production observed on the addition of D-histidine to organism 232 (Table 3 and Fig. 4) may be associated with the activity of a $\mathrm{D}$-amino acid oxidase. Most $\mathrm{D}$-amino acid oxidases of animal tissues and most micro-organisms so far studied attack D-histidine and other basic amino acids very slowly (review by Krebs, 1951). However, Stumpf \& Green (1946) reported that extracts of Proteus vulgaris and $P$. morganii oxidized $\mathrm{D}$-histidine. No figures were quoted but only three other $\mathrm{D}$-isomers (alanine, phenylalanine and phenylaminobutyrate) were attacked more rapidly than $D$-histidine. 
The organism studied in the present investigation may contain such an oxidase of low activity, though apart from the very slow oxidation of $D$-histidine (Table 3 ) the organism oxidized $\mathrm{D}$-phenylalanine but failed to oxidize the $\mathrm{D}$-isomers of valine, leucine, isoleucine, methionine or tryptophan. The failure of histamine and the ability of urocanic acid ( $\beta$-imidazole acrylic acid) to induce suggests that the $\alpha$-COOH group (of histidine) must remain intact for activity. More striking is the observation that $\beta$-(pyrazolyl-3)-alanine (I), differing from histidine (II) only in that the $\mathrm{CH}$ and $=\mathrm{N}$ - at the 2 and $\mathbf{3}$ positions, respectively, of the imidazole ring, are transposed, lacked inducing activity.

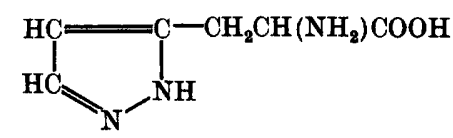

I

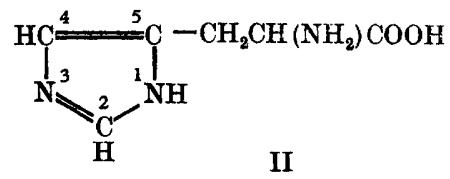

II

Pollock (1957) demonstrated that non-induced Bacillus cereus contained small levels of 'basal' penicillinase and the study of other induced enzymes for which a sufficiently sensitive assay exists has usually revealed the presence of small amounts of enzyme even in non-induced cells. Exposure of non-induced Paracolobactrum 232 to L-histidine under conditions precluding enzyme synthesis led to the liberation of the C-2 of the imidazole ring as $\mathrm{CO}_{2}$ (Fig. 3). Furthermore toluene-treated noninduced cells and extracts of them produce small amounts of ammonia and glutamate from L-histidine (Table 1). It seems reasonable to assume that the mechanism of the production of these substances is identical with that found in induced organisms and that non-induced organisms contain small quantities of the enzymes formed on induction by histidine. The data presented in Table 1 also support the view that noninduced organisms lack at least one of the enzymes responsible for L-histidine breakdown and that the adaptive process does not involve the synthesis of an inducible transport mechanism (or permease) of the type described in other bacterial systems (Rickenberg, Cohen, Buttin \& Monod, 1956; Green, 1956; Pardee, 1957). This conclusion is also supported by the fact that there was no lag in the evolution of ${ }^{14} \mathrm{CO}_{2}$ from (2-ring- ${ }^{14} \mathrm{C}$ )-L-histidine by non-induced organisms, an observation which suggests that these are permeable to L-histidine (Fig. 3).

The form of the curve relating enzyme formation induced by L-histidine with time (Fig. 6) is consistent with the idea that L-histidine, besides acting as inducer, was supplying respiratory energy, carbon skeletons or low molecular weight nitrogenous precursor material for enzyme synthesis. The course of enzyme synthesis under conditions where D-histidine was the inducing substance was linear (Fig. 7) and is comparable to 'gratuitous' conditions of induction (though the present experiments were conducted with washed suspensions and not with exponentially growing cultures). Markovitz \& Klein (1955) described a similar linear production of induced $\alpha$-amylase in washed suspensions of Pseudomonas saccharophila. The effect of succinate on the rate and final level of enzyme activity suggests that, in unsupplemented washed suspensions, the supply of respiratory substrates or carbon skeletons for synthetic purposes may have limited enzyme formation. Addition of ammonium chloride was without effect, suggesting that synthesis of enzyme in 'normal' organisms was not limited by supply of available nitrogen (Figs. 6, 7), 
though depletion of nitrogenous reserves by nitrogen starvation led to a decrease in the total enzyme produced in organisms induced with D-histidine (Table 4).

The author wishes to acknowledge the assistance of Dr M. E. Rhodes of the Department of Microbiology, University of Reading, who kindly identified the organism used in this investigation. He is indebted to the Committee of the Central Research Fund of the University of London for a grant for the purchase of a Hilger absorptiometer and to Mrs D. Collier for technical assistance.

\section{REFERENCES}

Berg, C. P. (1959). Utilization of D-amino acids. In Protein and Amino Acid Nutrition, p. 57. Ed. by A. A. Albenese. New York: Academic Press.

Bergey's Manual of Determinative Bacteriology (1957). Ed. R. S. Breed, E. G. D. Murray \& N. R. Smith. London: Baillière, Tindall and Cox.

Butrin, G., Cohen-Bazire, G. \& Monod, J. (1956). Cited in Monod, J. Remarks on the mechanism of enzyme induction. In Enzymes: Units of Biological Structure and Function, p. 7. Ed. by O. H. Gaebler. New York: Academic Press.

Chance, B. \& Williams, G. R. (1956). The respiratory chain and oxidative phosphorylation. Advanc. Enzymol. 17, 65.

Conrad, R. M. \& BErg, C. P. (1937). The optical inversion of $\mathbf{D}$-histidine in the animal body. J. biol. Chem. 117, 351.

Conway, E. J. (1947). Microdiffusion Analysis and Volumetric Error. London: Crosby Lockwood and Son Ltd.

Duerksen, J. D. \& Halvorson, H. (1959). The specificity of induction of $\alpha$-glucosidase in Saccharomyces cerevisiae. Biochim. biophys. Acta, 36, 47.

Edlbacher, S. \& Kraus, J. (1930). Zur Kenntnis des intermediären Stoffwechsels des Histidins. Hoppe-Seyl. Z. 191, 225.

Epps, H. (1945). Studies on bacterial amino acid decarboxylases. 4. L-Histidine decarboxylase from Clostridium welchii Type A. Biochem. J. 39, 42.

Folin, O. \& Denis, W. (1916). Nitrogen determination by direct nesslerization. I. Total nitrogen. J. biol. Chem. 26, 473.

Gale, E. F. (1945). Studies on amino acid decarboxylases. 5. The use of specific decarboxylase preparations in the estimation of amino acids and in protein analysis. Biochem.J. 39, 46.

Green, H. (1956). Cited in Davis, B. D. Relations between enzymes and permeability (membrane transport) in bacteria. In Enzymes: Units of Biological Structure and Function, p. 509. Ed. by O. H. Gaebler. New York: Academic Press.

Greenberg, D. M. (1954). Carbon catabolism of amino acids. In Chemical Pathways of Metabolism, vol. 2, p. 47. Ed. by D. M. Greenberg. New York: Academic Press.

Gunsalus, C. F., Stanier, R. Y. \& Gunsalus, I. C. (1953). The enzymatic conversion of mandelic acid to benzoic acid. III. Fractionation and properties of the soluble enzymes. J. Bact. 66, 548.

Henderson, L. M., \& Snelc E. E. (1948). A uniform medium for the determination of amino acids with various micro-organisms. J. biol. Chem. 172, 15.

Karlio, R. E. \& Larson, A. D. (1955). Methionine degradation by a species of Pseudomonas. In A symposium on Amino acid Metabolism, p. 616. Ed. by W. D. McElroy and H. B. Glass. Baltimore: Johns Hopkins Press.

Krebs, H. A. (1951). In The Enzymes, vol. II (i), p. 499. Ed. by J. B. Sumner and K. Myrbäck. New York: Academic Press.

MAGASANIK, B. (1953). Histidine assimilation and dissimilation in a histidine-less mutant of Aerobacter aerogenes. Fed. Proc. 12, 241.

Magasanik, B. \& Bowser, H. R. (1955). Pathways of L-histidine degradation in microorganisms. In A symposium on Amino Acid Metabolism, p. 398. Ed. by W. D. McElroy and H. B. Glass. Baltimore: Johns Hopkins Press. 
Markovitz, A. \& KLein, H. P. (1955). Some aspects of the induced biosynthesis of $\alpha$-amylase of Pseudomonas saccharophila. J. Bact. 70, 641.

Marr, A. G. \& Wilson, P. W. (1954). The alanine racemase of Brucella abortus. Arch. Biochem. 49, 424.

Martin, W. R. \& Foster, J. W. (1957). Adaptation patterns in the utilization of the stereoisomers of tartaric acid by a pseudomonad. J. Bact. 73, 683.

McIlwain, H. (1948). Preparation of cell-free bacterial extracts with powdered alumina. J. gen. Microbiol. 2, 288.

Mehrer, A. H. \& Tabor, H. (1953). Deamination of histidine to form urocanic acid in liver. J. biol. Chem. 201, 775.

Monod, J., Cohen-Bazire, G. \& Cohn, M. (1951). Sur la biosynthèse de la $\beta$-galactosidase (lactase) chez Escherichia coli. La spécificité de l'induction. Biochim. biophys. Acta, 7, 585.

Moore, S. \& Stein, W. H. (1948). Photometric ninhydrin method for use in the chromatography of amino acids. J. biol. Chem. 176, 367.

NARrod, S. A. \& Wood, W. A. (1952). Evidence for a glutamic acid racemase in Lactobacillus arabinosus. Arch. Biochem. 35, 462.

Pardee, A. B. (1957). An inducible mechanism for the accumulation of melibiose in Escherichia coli. J. Bact. 73, 376.

Polıock, M. R. (1957). Penicillin-induced resistance to penicillin in cultures of Bacillus cereus. In Drug Resistance in Micro-Organisms, p. 78. Ed. by G. E. W. Wolstenholme and C. M. O'Connor. London: J. and A. Churchill Ltd.

Rickenberg, H. V., Comen, G. N., Buttrn, G. \& Monod, J. (1956). La galactosideperméase d'Escherichia coli. Ann. Inst. Pasteur, 91, 829.

Rivière, J. W. M. la (1956). Specificity of whole cells and cell-free extracts of Pseudomonas putida towards (+), (-) and mesotartrate. Biochim. biophys. Acta, 22, 206.

SHrlo, M. (1957). The enzymic conversion of the tartaric acids to oxaloacetic acid. J. gen. Microbiol. 16, 472.

Shilo, M. \& Stanier, R. Y. (1957). The utilization of the tartaric acids by pseudomonads. J. gen. Microbiol. 16, 482.

Stewart, B. T. \& Halvorson, H. O. (1953). Studies on the spores of aerobic bacteria. I. The occurrence of alanine racemase. J. Bact. 65, 160.

Stumpf, P. K. \& Green, D. E. (1946). D-amino acid oxidase of Proteus morganii. Fed. Proc. 5, 157.

Suda, M., Mryahara, I., Tominata, K. \& Kato, A. (1952). Metabolism of histidine. I. The analysis of the enzymic breakdown of histidine. Med. J. Osaka Univ. 3, 115.

TABor, H. (1955). Degradation of histidine. In A Symposium on Amino Acid Metabolism, p. 373. Ed. by W. D. McElroy and H. B. Glass. Baltimore: Johns Hopkins Press.

Tabor, H. \& Hayarshi, O. (1952). The enzymatic conversion of histidine to glutamic acid. J. biol. Chem. 194, 171.

Tabor, H. \& Mehler, A. H. (1955). Preparation and assay of histidase and urocanase. Meth. Enzymol. 2, 228.

Thorne, C. B. \& Molnar, D. M. (1955). D-amino acid transamination in Bacillus anthracis. J. Bact. 70, 420.

Tristram, H. (1953). The adaptive oxidation of L-histidine by certain bacteria. J. gen. Microbiol. 9, vii.

Wickremasinghe, R. L. \& Fry, B. A. (1954). The formation of urocanic acid and glutamic acid in the fermentation of histidine by Clostridium tetanomorphum. Biochem. J. 58, 268.

Wood, W. A. \& Gunsalus, I. C. (1951). D-Alanine formation: a racemase in Streptococcus faecalis. J. biol. Chem. 190, 403. 